\title{
STATUS TERUMBU KARANG DI PERAIRAN PESISIR NEGERI HUKURILA
}

\section{(The Status of Coral Reef at Hukurila Village Coastal Waters)}

\author{
Dicky Sahetapy $^{1 *}$, Laura Siahainenia ${ }^{1}$, Debby A. J. Selanno ${ }^{1}$, Johannes M. S. Tetelepta ${ }^{1}$, \\ dan Novianty C. Tuhumury ${ }^{2}$ \\ 1) Program Studi Magister MSKP Pascasarjana Universitas Pattimura \\ 2) Jurusan Manajemen Sumberdaya Perairan Fakultas Perikanan dan Ilmu Kelautan Universitas Pattimura \\ dicky_sahetapy@yahoo.com, laura.siahainenia@gmail.com,debby_st@yahoo.co.id, \\ jms.tetelepta@fpik.unpatti.ac.id,y_louhen@yahoo.com \\ Corresponding author*
}

\begin{abstract}
ABSTRAK: Terumbu karang merupakan salah satu ekosistem pesisir penting yang emiliki kenanekaragaman hayati tinggi. Penelitian ini bertujuan untuk menganalisis komposisi taksa dan sebaran spesies karang, indeks ekologi kominitas karang dan status terumbu karang. Penelitian dilakukan dari April-Mei 2019 di perairan pesisir Negeri Hukurila Kecamatan Leitimur Selatan Kota Ambon. Pengumpulan data karang menggunakan metode Line Intercept Transect (LIT). Penentuan kondisi terumbu karang berdasarkan data (nilai) persen penutupan karang batu. Selama penelitian ditemukan 116 spesies karang batu dari 49 genera dan 16 famili, dimana 50 spesies diantaranya dilindungi dan 23 spesies karang hias. Indeks similaritas spesies karang batu antar stasiun terumbu karang berkisar antara 0,52-0,76 atau terdapat kesamaan spesies karang batu antar lokasi terumbu karang sebesar 52-76\%. Terumbu karang Negeri Hukurila memiliki diversitas spesies karang tinggi, dengan dominansi spesies karang rendah dalam komunitas, dan keserasian spesies karang dalam komunitas tergolong stabil. Karang Acropora memberi kontribusi nilai persen penutupan rendah $(9,98 \%)$, sementara karang Non-Acropora memberi kontribusi nilai persen penutupan karang batu relatif tinggi $(43,56 \%)$. Status terumbu karang antar stasiun terumbu perairan pesisir Negeri Hukurila berada dalam kriteria baik (sehat).
\end{abstract}

Kata kunci: terumbu, karang batu, keragaman spesies, kesamaan, persen penutupan

ABSTRACT : Coral reef is one of the important coastal ecosystems that have high biodiversity. This study aims to analyze the composition of the taxa and the distribution of coral species, the ecological index of coral communities and the status of coral reefs. The research was conducted from April-May 2019 in the coastal waters of Hukurila Village, South Leitimur District, Ambon City. Collecting coral data by using the Line Intercept Transect (LIT) method. Determination of coral reef condition based on percent data (value) of coral reef cover. During the study, 116 species of stony coral from 49 genera and 16 families were found, which 50 species of them are protected and 23 species of ornamental coral. The similarity index of stony coral species between coral reef locations ranges from $0.52-0.76$ or there is the similarity of stony coral species between locations coral reef in the amount of 52-76\%. The coral reefs of Hukurila Village have high diversity of coral species, with a low dominance of coral species in the community, and the compatibility of coral species in the community is classified as stable. Acropora corals contributed a low covering percent value $(9.98 \%)$, while Non-Acropora corals contributed a relatively high percent of covering value (43.56\%). The status of coral reefs between locations in the coastal waters of Hukurila Village is in the criteria of good (healthy).

Keywords: coral reefs, stony coral, species diversity, similarity, percent coverage 


\section{PENDAHULUAN}

Terumbu karang merupakan ekosistem utama perairan pesisir dan laut tropis, kehadirannya sangat dominan di perairan pesisir dan pulau-pulau kecil wilayah Kepulauan Indonesia. Sesuai Undang-Undang Nomor 4 Tahun 2011, luas terumbu karang Indonesia mencapai 2.517.858 ha (Giyanto $d k k, 2017$ ), terdiri atas terumbu karang tepi yang dominan, diikuti terumbu penghalang, atol dan terumbu tenggelam atau Patch Reef (Tuwo, 2011). Kondisi ini menyebabkan Indonesia ditetapkan sebagai pusat keanekaragaman hayati terumbu karang dunia, dan berada di pusat segitiga karang. Terumbu karang memiliki fungsi sebagai tempat tinggal sementara maupun permanen, mencari makan, memijah, asuhan, dan tempat berlindung berbagai spesies biota laut, serta tempat berlangsung siklus biologi, kimiawi dan fisik global. Terumbu karang memiliki produktivitas hayati yang tinggi, sebagai sumber bahan makanan, obat-obatan, dan bahan konstruksi (Suharsono, 2008).

Perairan pesisir dan pulau-pulau kecil (P3K) Provinsi Maluku memiliki tiga ekosistem utama tropis, dimana kehadiran ekosistem terumbu karang lebih dominan dibanding ekosistem mangrove dan padang lamun. Data tahun 2017 menunjukan luas terumbu karang di wilayah Provinsi Maluku adalah 439.110 ha atau $34.911 \mathrm{~km}^{2}$ (Giyanto $d k k, 2017$ ). Kenyataan tersebut memperkuat posisi Provinsi Maluku yang berada dalam Segitiga Karang (Coral Triangle) dunia. Akan tetapi fakta hasil penelitian menunjukan hanya $19,5 \%$ lokasi terumbu karang di wilayah Provinsi Maluku berada dalam kondisi sangat baik, 45,2\% dalam kondisi baik, dan 35,3\% lokasi terumbu karang di perairan $\mathrm{P} 3 \mathrm{~K}$ wilayah provinsi kepulauan ini telah berada dalam kondisi rusak. Rusaknya terumbu karang ini diakibatkan oleh tekanan antropogenik, terutama pemanfaatan sumberdaya perikanan pada ekosistem terumbu karang (Sahetapy, 2018a).

Pulau Ambon termasuk kategori pulau kecil sesuai batasannya dalam Undang Undang Nomor 1 Tahun 2014, dengan luas hanya 775 $\mathrm{km}^{2}$. Pulau Ambon terbagi atas dua wilayah administratif, yaitu Kota Ambon dengan luas $377 \mathrm{~km}^{2}$ dan $398 \mathrm{~km}^{2}$ sisanya termasuk wilayah administratif Kabupaten Maluku Tengah. Perairan pesisir Kota Ambon berada pada lima wilayah Kecamatan, dengan karakteristik dan kehadiran ekosistem tropis yang berbeda-beda. Perairan pesisir Negeri Hukurila yang berada dalam wilayah Kecamatan Leitimur Selatan memiliki ekosistem terumbu karang sangat dominan, tetapi belum tersedia data dari hasilhasil penelitian terumbu karang di perairan pesisir Negeri Hukurila ini.

Dalam rangka penentuan status terumbu karang Indonesia, Giyanto $d k k$ (2017) hanya mengambil 10 stasiun terumbu karang di Teluk Ambon untuk mewakili Pulau Ambon. Penelitian terumbu karang di wilayah Kecamatan Leitimur Selatan telah dilakukan oleh Sahetapy, $d k k$. (2006) di perairan pesisir Negeri Rutong dan Manuputty (2008) di pesisir Negeri Leahari. Dalam hal ini, belum tersedia data dan informasi hasil penelitian terumbu karang di perairan pesisir Negeri Hukurila. Selain itu, dalam rencana pembangunan Kota Ambon, maka Pemerintah Kota Ambon akan mengembangkan pariwisata, termasuk ekowisata bahari di pesisir dan perairan pesisir Negeri Hukurila. Namun demikian belum tersedia data dan informasi tentang kondisi eksisting terumbu karangnya sebagai salah satu objek wisata. Berbasis uraian latar belakang dan fakta hasil-hasil penelitian tersebut, maka penelitian ini dilaksanakan dengan tujuan menganalisis komposisi taksa dan sebaran spesies karang batu, indeks-indeks ekologi komunitas karang, serta kondisi terumbu karang di perairan pesisir Negeri Hukurila.

\section{METODE PENELITIAN}

Penelitian dilakukan dari bulan April hingga Mei 2019 pada empat stasiun (ST) terumbu karang di perairan pesisir Negeri Hukurila, Kecamatan Leitimur Selatan Kota Ambon (Gambar 1). Metode Line Intercept Transect (English et.al., 1997) digunakan untuk mengumpulkan data komponen penyusun terumbu karang dan komposisi taksa karang 
batu. Pada tiap stasiun terumbu karang diletakan $50 \mathrm{~m}$ garis transek pada kedalaman air 3-7 m ke zona tubir terumbu mengikuti perkembangan optimum terumbu karang. Guna memperoleh data kekayaan taksa karang batu, juga dilakukan koleksi bebas di luar areal transek dengan cara berenang melintasi zona rataan hingga zona tubir terumbu karang, kemudian mencatat taksa karang dan mengoleksi contoh karang yang tidak teridentifikasi secara in situ.

Identifikasi dan klasifikasi spesies karang batu mengacu pada sejumlah buku identifikasi karang, yaitu Veron\&Pichon (1976, 1979, 1982), Veron\&Wijsman-Best (1977), Randall\&Myers (1983), Veron (1986, 2000, 2002), dan Suharsono (2008). Nilai persen penutupan karang batu dianalisa menggunakan pendekatan menurut English, et al. (1997). Kesamaan (similaritas) spesies karang batu antar stasiun terumbu karang dianalisa menggunakan formula Similarity Index (Odum, 1971). Indeks-Indeks ekologi komunitas (Diversitas, Dominansi, Keserasian spesies) karang dianalisa dengan formula Indeks Shanonn, Simpson dan Indeks Evenness (Odum (1975). Selain itu, penilaian nilai indeks ekologi komunitas karang tersebut merujuk pada kriteria dari Deget (1976). Status terumbu karang tiap stasiun terumbu ditentukan merujuk pada Kriteria Baku Kerusakan Terumbu Karang dalam Kep. Meneg. L.H No. 4 Tahun 2001, yaitu:

- Kriteria Sangat Baik, jika nilai persen penutupan karang batu 75-100\%.

- Kriteria Baik, jika nilai persen penutupan karang batu 50-74,9\%.

- Kriteria Sedang (Rusak), jika nilai persen penutupan karang batu 25-49,9\%.

- Kriteria Buruk (Miskin), jika nilai persen penutupan karang batu $0-24,9 \%$.

\section{HASIL DAN PEMBAHASAN}

\section{Komposisi Taksa Dan Sebaran Spesies Karang}

Hasil identifikasi dan klasifikasi menunjukan terumbu karang Negeri Hukurila memiliki 116 spesies karang batu dari 49 genera dan 16 famili (Gambar 2). Indonesia merupakan pusat keragaman spesies karang batu tertinggi di dunia (Chou, 2000), memiliki 590 spesies karang dari 80 marga (Suharsono, 2008), sementara Laut Banda dengan 533 spesies karang batu (Green dan Mous, 2008), pulaupulau Raja Ampat dengan 456 sepesies karang yang termasuk dalam 77 genera (Veron, 2002), dan perairan P3K Provinsi Maluku memiliki 312 spesies karang batu dari 74 genera (Sahetapy, 2018a).

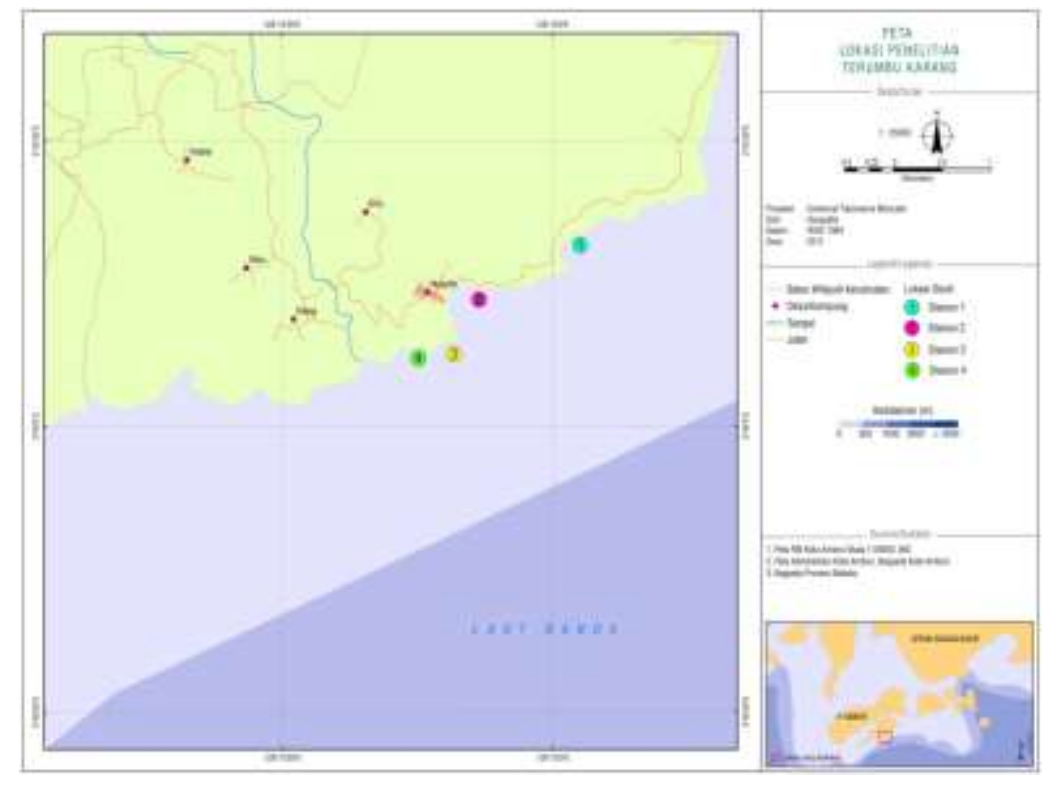

Gambar 1. Peta lokasi penelitian terumbu karang di perairan pesisir Negeri Hukurila 
Dengan demikian, 19,7\% kekayaan spesies karang di perairan Indonesia, 21,8\% spesies karang di kawasan Laut Banda, 25,4\% spesies karang di perairan pulau-pulau Raja Ampat, dan 37,2\% spesies karang batu di perairan P3K Provinsi Maluku teridentifikasi menempati terumbu karang Negeri Hukurila. Kekayaan spesies karang batu di terumbu karang lokasi penelitian lebih tinggi dari terumbu karang di Negeri Leahari yang memiliki 75 spesies karang (Manuputty, 2008), serta lebih tinggi dari terumbu karang Negeri Rutong yang hanya memiliki 61 spesies karang (Sahetapy $d k k$, 2006). Namun demikian, kekayaan spesies karang batu di terumbu karang lokasi penelitian lebih rendah dibanding 533 spesies karang batu di Laut Banda (Green\& Mous, 2008) dan 312 spesies karang di perairan P3K Provinsi Maluku (Sahetapy, 2018a). Terdapat empat famili karang yang memiliki kekayaan spesies tinggi yaitu Faviidae (27 spesies), Acroporidae (24 spesies), Fungiidae (13 spesies) dan Poritidae (11 spesies). Kenyataan ini didukung Suharsono (1986) bahwa karang batu famili Acroporidae, Faviidae, Fungiidae dan Poritidae memiliki kekayaan spesies tinggi di perairan Indonesia, juga di perairan P3K Provinsi Maluku (Sahetapy, 2018a). Kekayaan spesies dan genera karang batu di terumbu ST1 lebih tinggi dari tiga stasiun terumbu lain, terutama terumbu karang ST2 (Gambar 2). Dalam hal ini, 61\% dari spesies karang batu di terumbu karang Negeri Hukurila bisa ditemukan di terumbu
ST1, sementara hanya $48 \%$ dari spesies karang batu bisa ditemukan di terumbu ST2.

Kekayaan spesies karang pada lokasi penelitian berkisar antara 56-71 spesies (Gambar 2), dengan nilai rerata 64 spesies per stasiun terumbu. Rerata jumlah spesies karang tersebut relatif lebih rendah dibanding rerata jumlah spesies karang di Kepulauan Raja Ampat (Fenner, 2002), yaitu 87 spesies per lokasi terumbu dan rerata jumlah spesies karang di Teluk Tuhaha (68 spesies) karang per lokasi terumbu (Sahetapy $d k k$, 2018). Hal ini disebabkan oleh perbedaan variasi substrat dasar dan kondisi fisik perairan sebagai penentu kehadiran dan pertumbuhan karang secara baik (Dutton, et.al., 2001), juga faktor luas terumbu dan jumlah stasiun terumbu karang yang diamati (Sahetapy, 2015; Sahetapy $d k k, 2018$ ).

Sebanyak 25 spesies karang batu menyebar luas, sementara 47 spesies karang batu menyebar terbatas. Stasiun terumbu karang dengan jumlah spesies karang menyebar terbatas relatif tinggi pada ST3 (16 spesies) dan ST1 (15 spesies), sementara terumbu ST2 memiliki jumlah spesies karang menyebar terbatas yang rendah (4 spesies). Secara teoritis, 47 spesies karang yang menyebar terbatas ini sangat rentan terhadap tekanan pemanfaatan yang bisa menurunkan populasinya, dan mikro habitatnya mengalami perubahan. Oleh karena itu, upaya pengelolaan habitat dan potensi 47 spesies karang batu yang menyebar terbatas menjadi prioritas untuk dilakukan guna menjamin eksistensi dan keberlanjutan potensi.

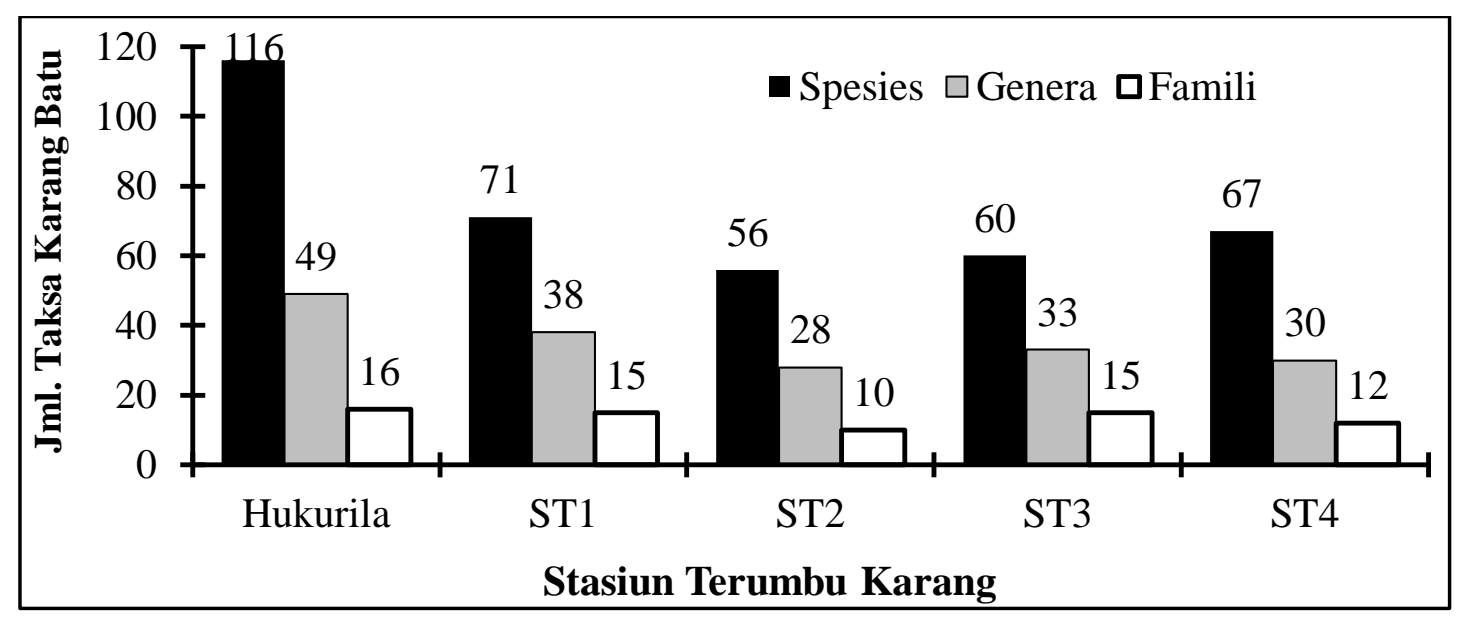

Gambar 2. Fluktuasi jumlah taksa karang batu di terumbu karang Negeri Hukurila 
Nilai indeks kesamaan spesies karang batu antar stasiun terumbu karang berkisar antara 0,52-0,76 atau kesamaan spesies karang batu antar stasiun terumbu sebesar 52\%-76\%. Jika dirinci menurut pasangan stasiun terumbu karang, maka kesamaan spesies karang batu antara terumbu karang ST1 dan ST2 adalah tinggi (76\%), sementara kesamaan spesies karang batu antara terumbu karang ST2 dan ST3 relatif rendah (52\%). Uraian tersebut mengindikasikan bahwa ada ketidaksamaan spesies karang batu antar stasiun terumbu karang sebasar 0,24-0,48 (24\%-48\%). Ketidaksamaan spesies karang batu antar terumbu karang ini menunjukan keempat stasiun terumbu memiliki mikro-habitat spesifik pada salah satu staiun terumbu tertentu dan spesiesspesies karang itu tidak bisa hadir di stasiun terumbu lain. Oleh karena itu, habitat terumbu pada empat stasiun terumbu karang Negeri Hukurila harus dikelola untuk menjamin keberlanjutan fungsi ekologis habitat terumbu karang.

Terumbu karang Negeri Hukurila memiliki 50 spesies karang batu yang dilindungi (Tabel 1), terdiri atas 3 spesies karang terancam punah (Endangered species), 5 spesies karang rentan punah (Vulnerable species), 38 spesies karang hampir terancam (Near threatened), dan 4 spesies karang kategori spesies yang mendapat perhatian terakhir (Least concern species). Kekayaan spesies karang yang dilindungi ini lebih rendah dari perairan pesisir dan pulau-pulau kecil Provinsi Maluku (Sahetapy, 2018a) yaitu 97 spesies, yang terdiri atas 5 spesies karang kategori terancam punah, 11 spesies karang rentan punah, 70 spesies karang hampir terancam, dan 11 spesies karang kategori mendapat perhatian terakhir.
Ditemukan tiga spesies karang kategori terancam punah di terumbu karang Negeri Hukurila, yaitu Acropora rudis, Stylocoeniella armata dan Archelia horrescens. Selanjutnya, lima spesies karang famili Acroporidae (Acropora aspera, A. donei, A.horrida, A. multiacuta, A. speciosa) yang termasuk spesies rentan punah. Selain 38 spesies karang dilindungi kategori hampir terancam, ditemukan empat spesies karang kategori least concern yaitu Acropora clathrata, A. monticulosa, A. tenuis dan A. smoensis di terumbu karang Negeri Hukurila. Secara spasial, terumbu karang ST4 memiliki kekayaan spesies karang dilindungi relatif banyak (34 spesies) dibanding tiga stasiun terumbu karang lain (Tabel 1). Secara teoritis, perbedaan kekayaan spesies karang yang dilindungi pada empat stasiun terumbu karang ini disebabkan oleh variasi lingkungan biofisik habitat setiap lokasi terumbu yang ternyata berbeda-beda (Sahetapy $d k k, 2018$; Sahetapy, 2018b).

Spesies karang batu kategori terancam punah hanya berada di terumbu karang ST1 dan ST4 (Tabel 1). Walaupun terumbu karang ST2 dan ST3 tidak memiliki spesies karang terancam punah, tetapi kedua stasiun terumbu karang ini memiliki spesies karang kategori rentan punah. Selain itu, keempat stasiun terumbu karang memiliki kekayaan spesies karang batu kategori hampir terancam yang banyak dan relatif sama banyak. Uraian hasil analisis tersebut memberikan suatu isyarat bahwa harus dilakukan upaya konservasi terhadap 50 spesies karang batu yang dilindungi, termasuk perlindungan terhadap areal terumbu karang sebagai habitat hidupnya.

Tabel 1. Kekayaan spesies karang batu menurut kategori konservasi

\begin{tabular}{cccccc}
\hline \multirow{2}{*}{$\begin{array}{c}\text { Stasiun } \\
\text { Terumbu }\end{array}$} & Endangered & Vulnerable & Near Threatened & $\begin{array}{c}\text { Least } \\
\text { Concern }\end{array}$ & Total Species \\
\cline { 2 - 5 } & 1 & 1 & 25 & 2 & 29 \\
ST1 & 0 & 2 & 21 & 3 & 26 \\
ST2 & 0 & 1 & 24 & 1 & 26 \\
ST3 & 2 & 3 & 25 & 4 & 34 \\
ST4 & 3 & 5 & 38 & 4 & 50 \\
\hline Hukurila & & & & & \\
\hline
\end{tabular}


Terumbu karang Negeri Hukurila memiliki 23 spesies karang hias (Gambar 3) bernilai ekonomis berkaitan dengan industri akuarium air laut. Kekayaan spesies karang hias ini merupakan 33,3\% dari 69 spesies karang hias yang menempati terumbu karang perairan pesisir dan pulau-pulau kecil Provinsi Maluku (Sahetapy, 2018a). Secara spasial, kekayaan spesies karang hias di terumbu karang ST1 lebih tinggi dari tiga stasiun terumbu karang yang lain, terutama ST3. Setidaknya 18 spesies dari 23 spesies karang hias tersebut merupakan spesies karang yang dilindungi, yaitu Acropora gemmifera, A. humilis, Montipora carpricornis, Pachyseris speciosa, Tubastrea micrantha, Turbinaria reniformis, Halomitra pileus, Herpolita limax, Polyphyllia talpina, Merulina ampliata, Galaxea fascicularis, Mycedium elephantotus, Oxypora lacera, Pectinia lactuca, Pocillopora eydouxi, P. verrucosa (Near Threathened Species) dan Acropora tenuis (Least Concern Species).

Deskripsi data tersebut mengindikasikan terumbu karang Negeri Hukurila menyimpan potensi spesies karang hias cukup besar. Ini berarti, ada suatu potensi ekonomis penting jika dikelola berbasis konsep pemanfaatan berkelanjutan, yaitu usaha budidaya karang hias. Dalam hal ini, budidaya karang hias menjadi solusi untuk menghindari tekanan pemanfaatan karang hias secara langsung di alam.

\section{Indeks-Indeks Ekologi Komunitas Karang}

Sehubungan dengan upaya pengelolaan, konservasi spesies karang batu dan terumbu karang sebagai habitatnya, serta evaluasi dan monitoring guna menunjang wisata bahari berkelanjutan maka data dan informasi tentang indeks-indeks ekologi komunitas karang sangat penting, dan harus disediakan. Oleh karena itu, dilakukan analisis nilai Indeks Diversitas, Dominansi dan Keserasian spesies karang dalam komunitas pada empat stasiun terumbu karang (Tabel 2).

Nilai indeks diversitas spesies karang batu di terumbu karang Negeri Hukurila termasuk kriteria tinggi $(\mathrm{H}>3)$, dengan nilai indeks dominansi spesies karang batu di dalam komunitas pada empat stasiun terumbu karang termasuk kriteria rendah. Kenyataan ini merupakan hal yang wajar pada suatu komunitas biota (termasuk komunitas karang). Jika nilai indeks diversitas spesies tinggi maka nilai indeks dominansi spesies di dalam komunitas rendah $(0.00<\mathrm{D} \leq 0.50)$. Selabaliknya, jika nilai indeks diversitas spesies suatu kumunitas biota rendah maka nilai indeks dominansi spesies biota (termasuk komunitas karang) di dalam komunitasnya tinggi (Odum, 1975; Hukom, 2010; Sahetapy $d k k, 2018$ ).

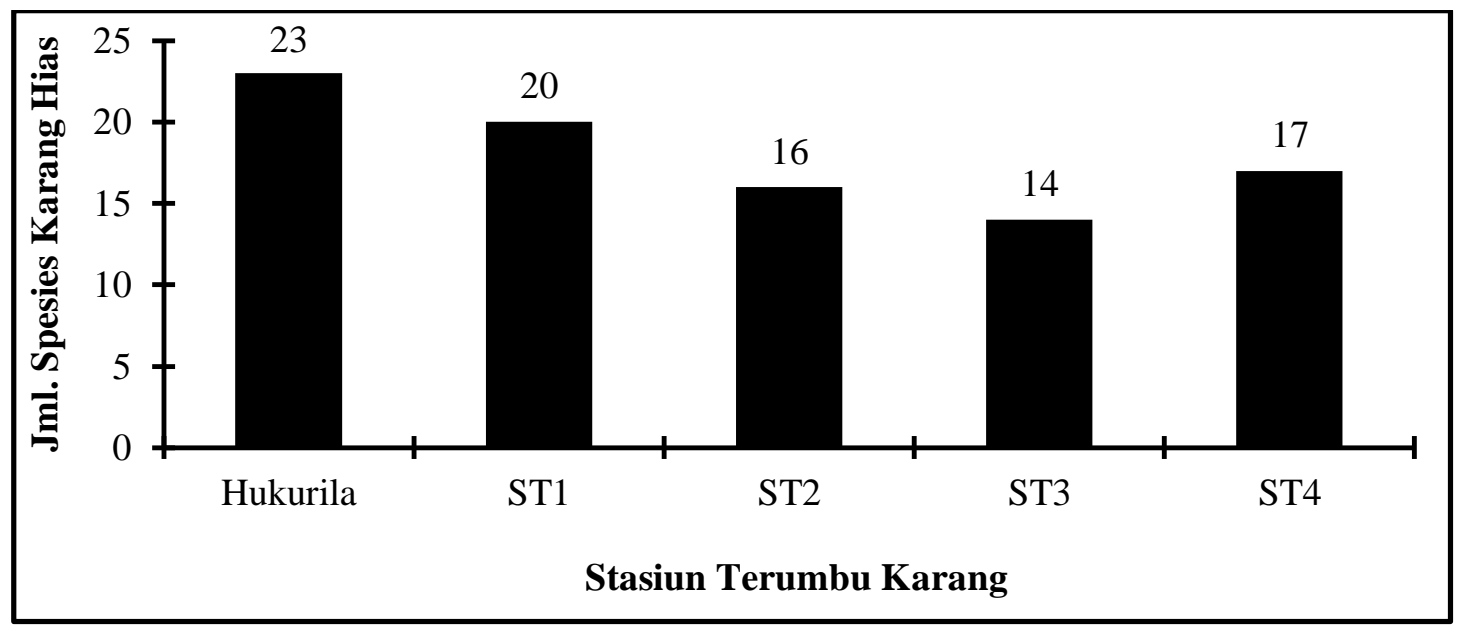

Gambar 3. Kekayaan spesies karang hias antar lokasi terumbu karang 
Tabel 2. Nilai-nilai indeks ekologi komunitas karang antar stasiun terumbu karang

\begin{tabular}{ccccccc}
\hline Lokasi & \multicolumn{2}{c}{ Indeks Shannon } & \multicolumn{2}{c}{ Indeks Simpson } & \multicolumn{2}{c}{ Indeks Evenness } \\
\cline { 2 - 6 } Terumbu & H & Kriteria & D & Kriteria & E & Kriteria \\
\hline ST1 & 3,75 & Tinggi & 0,036 & Rendah & 0,92 & Stabil \\
ST2 & 3,79 & Tinggi & 0,027 & Rendah & 0,96 & Stabil \\
ST3 & 3,42 & Tinggi & 0,046 & Rendah & 0,89 & Stabil \\
ST4 & 3,77 & Tinggi & 0,029 & Rendah & 0,95 & Stabil \\
\hline Hukurila & 3,68 & Tinggi & 0,035 & Rendah & 0,93 & Stabil \\
\hline
\end{tabular}

Spesies karang batu kategori jarang (2237 spesies) memberi kontribusi signifikan pada nilai indeks diversitas spesies karang batu dalam komunitas. Sebaliknya, spesies karang batu kategori umum atau dominan (1-3 spesies) memberi kontribusi relatif kecil pada nilai indeks dominansi spesies karang batu di dalam komunitas tiap stasiun terumbu karang. Oleh karena itu, dalam upaya pengelolan terumbu karang pada lokasi penelitian, maka spesies karang kategori jarang (jumlah koloni sedikit) menjadi penting untuk dikelola. Jika spesiesspesies karang batu kategori jarang itu hilang karena tekanan lingkungan dan pemanfaatan, dapat dipastikan diversitas spesies karang batu di dalam komunitas tiap satsiun terumbu karang menjadi rendah. Apabila diversitas spesies karang batu di dalam komunitas rendah, diyakini akan berdampak negatif terhadap wisata selam (diving) dan renang (snorkelling) yang umumnya mengutamakan ekowisata bahari berkelanjutan.

Menurut Odum (1975), jika nilai Indeks Evenness suatu komunitas biota berkisar antara 0,6-0,8 maka komunitas biota itu berada dalam kondisi berimbang (steady state). Apabila pernyataan itu dihubungkan dengan hasil analisis (Tabel 2), maka spesies karang dalam komunitas pada empat stasiun terumbu karang dalam kondisi tidak berimbang karena nilai Indeks Evenness lebih besar dari 0.8. Akan tetapi, jika hasil analisis (Tabel 2) dihubungkan dengan kriteria penilaian dari Deget (1976), Hukom (2010), Huliselan, et al. (2019) maka keserasian spesies karang batu dalam komunitas keempat stasiun terumbu karang Negeri Hukurila berada dalam kriteria stabil $(0.75>\mathrm{E} \leq 1.00)$.
Sesuai uraian tersebut, dapat dikatakan diversitas spesies karang batu di terumbu karang Negeri Hukurila tergolong tinggi, dengan dominansi spesies karang yang rendah dalam komunitas. Komunitas karang berada dalam kondisi tidak berimbang, tetapi keserasian spesies karang di dalam komunitas berada dalam kriteria stabil. Simpulan ini dapat digunakan sebagai dasar untuk tiga hal penting, yaitu (a) menilai, mengelola dan melindungi komunitas karang, (b) menjadi dasar monitoring dan evaluasi diversitas, dominansi dan keserasian spesies karang pada terumbu karang, dan (c) menjadi dasar perencanaan dan pengembangan ekowisata bahari kategori diving dan snorkeling di perairan pesisir Negeri Hukurila.

\section{Kondisi Terumbu Karang}

Karang Non-Acropora memiliki nilai persen penutupan dasar terumbu karang lebih tinggi dari karang Acropora. Karang NonAcropora bentuk tumbuh karang masif (CM), karang foliouse $(\mathrm{CF})$ dan karang encrusting (CE) memiliki nilai persen penutupan dasar terumbu yang tinggi dibanding karang Acropora palifera dari bentuk tumbuh Acropora submasif (ACS) di terumbu karang ST1 dan ST2. Berdasarkan pengamatan lapangan, karang Acropora dari bentuk tumbuh branching (ACB) dan Acropora tabulate (ACT) berdiameter koloni kecil. Berbasis deskripsi tersebut dan terutama letak dari terumbu karang, dapat dikatakan bahwa faktor alam yaitu gelombang menghambat kehadiran karang Acropora dengan diameter koloni besar, sementara karang Non-Acropora bentuk tumbuh CM, CF dan CE bisa beradaptasi dan berkembang di terumbu 
karang Negeri Hukurila yang mendapat tekanan gelombang selama musim timur.

Berbasis hasil analisis persen penutupan karang (Tabel 3) dan Kriteria Baku Kerusakan Terumbu Karang (Kep. Meneg. LH. No. 4 Tahun 2001), maka status terumbu karang Negeri Hukurila termasuk kriteria baik (sehat). Hasil monitoring tahun 1993-2001 menunjukan $5,3 \%$ terumbu karang Indonesia termasuk kriteria sangat baik, 27,2\% kriteria baik, 37,3\% kriteria sedang, dan 30,5\% dalam kriteria buruk (Susanto et al, 2015). Status terumbu karang itu mengalami perubahan setelah dikeluarkan data status terumbu karang Indonesia tahun 2017 (Giyanto $d k k$, 2017), dimana status terumbu karang Indonesia kriteria sangat baik meningkat menjadi $6,39 \%$, kriteria baik menurun menjadi $23,40 \%$, kriteria sedang menurun menjadi $35,06 \%$ dan kriteria buruk meningkat menjadi $35,15 \%$. Jika hasil analisis dibandingkan dengan kedua data status terumbu karang Indonesia itu, tidak ditemukan terumbu karang kriteria sangat baik, sedang dan buruk di perairan pesisir Negeri Hukurila.

Pada dasarnya status suatu terumbu karang alami selalu berada pada kriteria sangat baik dengan diameter koloni karang yang besar sebagai indikator kematangan komunitasnya, dan berimplikasi pada tingginya nilai persen penutupan karang batu (Sahetapy, 2003; Sahetapy\&Far-Far, 2008). Sesuai pendapat itu, maka areal terumbu karang Negeri Hukurila dengan kriteria baik berasal dari kriteria sangat baik. Namun demikian, akibat tekanan faktor alam yaitu gelombang di musim timur dan tekanan antropogenik terkait pemanfaatan sumberdaya terumbu karang dan areal pesisir sekitar terumbu karang (Dutton, et al., 2001; Supriharyono, 2007; Sahetapy, 2010a; Sahetapy, 2018b; Sahetapy, 2011; Sahetapy $d k k$, 2018), maka terumbu karang di perairan pesisir Negeri Hukurila mengalami degradasi, dan status terumbu karang telah berada pada kriteria baik (sehat).

Jika ditelusuri secara spasial, terumbu karang ST2 dan ST4 berada pada kriteria baik, tetapi nilai persen penutupan karang batu telah mendekati batas atas kriteria sedang (penutupan karang 25-49,9\%). Hal ini disebabkan adanya kegiatan pemanfaatan sumberdaya terumbu karang yang berpotensi merusak terumbu karang pada kedua stasiun itu. Pernyataan ini dibuktikan oleh nilai persen penutupan patahan karang mati (rubble), karang mati ditutupi alga (DCA) dan fauna lain (other fauna) relatif tinggi di terumbu karang ST2 dan ST4. Dalam hal ini, status terumbu karang ST2 dan ST4 kriteria baik saat penenlitian akan menurun ke status terumbu karang kriteria rusak jika aktivitas permanfaatan sumberdaya terumbu karang maupun daerah pesisir sekitar terumbu karang pada kedua stasiun ini tidak dihentikan.

Berbasis uraian singkat status terumbu karang yang dikemukakan, maka diperlukan upaya penanggulangan guna menjamin eksistensi dan meningkatkan status terumbu karang di perairan pesisir Negeri Hukurila, sebagai berikut:

1. Dinas Perikanan Kota Ambon menghentikan penerbitan ijin penangkapan ikan di terumbu karang Negeri Hukurila, dan melakukan pengawasan yang ketat.

Tabel 3. Komponen penyusun dan kondisi terumbu karang Negeri Hukurila

\begin{tabular}{crccccc}
\hline \multirow{2}{*}{$\begin{array}{c}\text { Stasiun } \\
\text { Terumbu }\end{array}$} & \multicolumn{5}{c}{ Nilai Persen Penutupan (\%) Komponen } & Kriteria \\
\cline { 2 - 5 } & Abiotik & DCA & Algae & Fauna Lain & $\begin{array}{c}\text { Karang } \\
\text { Batu }\end{array}$ & Terumbu \\
\hline ST1 & 11,02 & 4,60 & 2,44 & 14,70 & 67,24 & Baik \\
ST2 & 14,06 & 8,66 & 3,48 & 21,56 & 52,24 & Baik \\
ST3 & 18,58 & 4,82 & 1,34 & 8,40 & 66,86 & Baik \\
ST4 & 9,46 & 6,02 & 3,20 & 28,18 & 53,54 & Baik \\
\hline Hukurila & 13,30 & 6.03 & 2,60 & 18,20 & 60,00 & Baik \\
\hline
\end{tabular}


2. Dinas Pariwisata Kota Ambon bersama masyarakat Negeri Hukurila dan pemangku kepentingan terkait menata dan mengawasi aktivitas wisata di pantai dan perairan pesisir, agar tidak berdampak buruk pada terumbu karang sebagai aset penting dalam pengembangan ekowisata bahari kategori snorkeling di terumbu stasiun 3 dan diving di terumbu karang stasiun 1, stasiun 2 dan stasiun 4.

\section{KESIMPULAN DAN SARAN}

Terumbu karang Negeri Hukurila memiliki 116 spesies karang batu dari 49 genera dan 16 famili, 50 spesies karang dilindungi dan 23 spesies karang hias. Famili Faviidae, Acroporidae, Fungiidae dan Poritidae memiliki kekayaan spesies karang tinggi. Kekayaan dan variasi spesies karang batu antar lokasi terumbu karang relatif rendah (64 spesies karang per lokasi terumbu karang). Kesamaan spesies karang batu antar stasiun terumbu karang berkisar antara 52\%-76\% dan ketidaksamaan spesies karang batu antar stasiun terumbu karang sebesar $24 \%-48 \%$. Sebanyak 25 spesies karang batu menyebar luas dan 47 spesies menyebar terbatas. Diversitas spesies karang batu tergolong tinggi, dengan Dominansi spesies karang yang rendah, dan Keserasian spesies karang batu dalam komunitas berada pada status stabil. Status terumbu karang di perairan pesisir Negeri Hukurila berada pada kriteria baik atau sehat.

Berdasarkan hasil penelitian maka dapat diberikan dua saran (rekomendasi) sebagai berikut:

1. Pemerintah Kota Ambon berkerjasama dengan lembaga pendidikan tinggi terkait untuk membuat Zonasi Rinci terumbu karang Negeri Hukurila dan menyusun Rencana Aksi Pengeloaannya.

2. Pemerintah Negeri Adat Hukurila mengoptimalkan peranan Lembaga Kewang dan menerapkan nilai-nilai konservasi pada Sistem Sasi dalam mengawasi keberadaan ekosistem terumbu karang serta bentukbentuk pemanfaatan yang berdampak negatif terhadap eksistensi terumbu karang dan sumberdaya hayatinya.

\section{UCAPAN TERIMAKASIH}

Artikel ini ditulis atas ijin penggunaan data Kajian Kelayakan Pengembangan Pariwisata di Negeri Hukurila, yang dibiayai Pemerintah Kota Ambon. Ucapan terima kasih juga disampaikan kepada mereka yang telah mereview artikel ilmiah ini.

\section{DAFTAR PUSTAKA}

Chou, L.M. 2000. Southeast Asia Reef-Status Update: Cambodia, Indonesia, Malaysia, Philippines, Singapore, Thailand and Vietnam. In C. Wilkinson, Status of coral reefs of the world, CORDIO, pp: 129 - 117.

Deget. 1976. Les Mode'les Mathematiques en Ecologie. (Paris: Masson, Coll. Ecol. 8): 172 p.

Dutton, I.M., D.G. Bengen, J.J. Tulungen, 2001. The Challenges of Coral Reef Management in Indonesia. In E. Wolanski (2001), Oceanographic Processes of Coral Reefs: Physical and Biological Link in the Great Barrier Reef. CRC Press LLC, pp: 315-330.

English S., C. Wilkinson, V. Baker. 1997. Survey Manual For Tropical Marine Resources. ASEAN-Australia Marine Science Project: Living Coast Resources.

Fenner D. 2002. Reef corals of the Raja Ampat Islands, Papua Province, Indonesia. RAP Bulletin of Biological Assessment 22, 29-36.

Giyanto, M. Abrar, T.A, Hadi, A. Budiyanto, M. Hafizt, A. Salatalohy, M.Y. Iswari. 2017. Status Terumbu Karang Indonesia 2017. COREMAP-CTI, Pusat Penelitian Oseanografi- LIPI: 30 hal, ISBN 978-6026664-09-9.

Green A.L and P. Mous, 2008. Delineating The Coral Triangle, Its Ecoregions and Functional Seascapes. Version 5.0. TNC Coral Triangle Prog. Rep. 1/08: 44 p.

Hukom F.D. 2010. Biodiversitas dan Kondisi Ikan Karang Pada Beberapa Lokasi di Perairan Terumbu Karang Kabupaten Flores Timur, NTT. Prosiding Seminar Nasional Biologi. Fakultas Biologi UGM, Yolyakarta. 200-221.

Huliselan N.V., D. Sahetapy, M.A. Tuapattinaja, M. Wawo. 2019. Community Structure of Target 
Reef Fish at Four Tiny Islands Coral Reef in Inner Kotania Bay, Maluku Province, Indonesia. IOP Conf. Series: Earth and Environmental Science 339 (2019) 012005 doi:10.1088/1755-315/339/1/012015: 8 p.

Keputusan Menteri Negara Lingkungan Hidup Nomor 04 Tahun 2001, Tentang Kriteria Baku Kerusakan Terumbu Karang.

Manuputty, J. 2008. Eksplorasi Terumbu Karang di Perairan Pesisir Desa Leahari, Kecamatan Leitimur Selatan. Skripsi. Fakultas Perikanan dan Ilmu Kelautan Universitas Pattimura.

Odum, E.P. 1971. Fundamental of Ecology. W.B. Sounders, Philadelphia.

Odum, E.P. 1975. Ecology. The Link Between the Natural and The Social Science. Second Edition. Rinehart and Winston: pp. 53-56.

Randall, R.H. \& R.F. Myers. 1983. Guide to the Coastal Resources of Guam. The Coral. University of Guam Press. Vol. II. 128 pp.

Sahetapy, D., Y.A. Lewerissa, R. Siahainenia. 2006. Potensi Sumberdaya Terumbu Karang di Perairan Pesisir Negeri Rutong. Prosiding Seminar: Potensi dan Peluang Pengembangan Sumberdaya Hayati Pesisir Desa Rutong. Jurusan MSP, Fakultas Perikanan dan Ilmu Kelautan Universitas Pattimura. 94-113.

Sahetapy, D. 2003. Struktur komunitas karang di perairan pesisir Pulau Larat, Kabupaten Maluku Tenggara Barat. TRITON: Jurnal Manajemen Sumberdaya Perairan 2(1): 8388.

Sahetapy, D. \& R. Far-Far. 2008. Kondisi Terumbu Karang di Perairan Pesisir Pulau-Pulau Kecil Kecamatan Gorom, Kabupaten Seram Bagian Timur. Prosiding KONAS VI : Pengelolaan Sumberdaya Pesisir dan Laut. Departemen KP- RI: hal. 474 - 485.

Sahetapy, D. 2010a. Sebaran Spesies Karang Batu Dan Kondisi Terumbu Karang di Perairan Pesisir Dan Pulau-Pulau Kecil Provinsi Maluku. Prosiding KONAS VII: Pengelolaan Sumberdaya Pesisir, Laut dan Pulau-Pulau Kecil.

Sahetapy, D. 2010b. Eksistensi Terumbu Karang di Perairan Pesisir Teluk Ambon. TRITON: Jurnal Manajemen Sumberdaya Perairan 6(2): 61-70.

Sahetapy, D., 2011. The Existing Condition of Coral Reef In the Coastal Waters and Small Islands Region of Southwest Maluku Regency, Maluku Province. Proceeding International
Seminar on Role of Postgraduate Study in Sustainability Development of Archipelagic Communities. Published by Postgraduate of Pattimura University and Indonesan Postgraduate Leaders Forum: p. 69-80.

Sahetapy, D. 2015. Kondisi Terumbu Karang di Perairan Pesisir Dan Pulau-Pulau Kecil, Kabupaten Kepulauan Aru Provinsi Maluku. Prosiding Pertemuan Ilmiah Tahunan (PIT) XI ISOI Balikpapan 17-18 November 2014. Ikatan Sarjana Oseanologi Indonesia, hal: 236-254.

Sahetapy, D., A.S.W Retraubun, D.G Bengen, J. Abrahamsz. 2018. Kondisi Eksisting Terumbu Karang di Perairan Teluk Tuhaha, Kabupaten Maluku Tengah. Prosiding Seminar Nasional Inovasi IPTEK Kelautam dan Perikanan I, Vol. 1: hal 77 - 90.

Sahetapy, D. 2018a. Kekayaan Spesies Karang Batu Dan Kondisi Terumbu Karang Perairan Pesisir Dan Pulau-Pulau Kecil Provinsi Maluku. Dalam Buku: Pengelolaan Lingkungan dan Sumberdaya Laut, Pesisir dan Pulau-Pulau Kecil. Fakultas Perikanan dan Ilmu Kelautan Universitas Pattimura, Ambon. ISBN 978-602-53210-0-9: 23 - 36

Sahetapy, D. 2018b. Kondisi Eksisting Terumbu Karang di Taman Wisata Alam Laut Pulau Kasa, Kabupaten Seram Bagian Barat. Prosiding Seminar Nasional Inovasi IPTEK Kelautam dan Perikanan I, Vol.1: hal. 420436.

Suharsono. 1986. Jenis-Jenis Karang Yang Umum Dijumpai di Perairan Indonesia. Lembaga Ilmu Pengetahuan Indonesia. Puslitbang Oseanlologi Press, Jakarta.

Suharsono. 2008. Jenis-Jenis Karang di Indonesia. Lembaga Ilmu Pengetahuan Indonesia. LIPI Press, Anggota Ikapi, Jakarta.

Supriharyono. 2007. Konservasi Ekosistem Sumberdaya Hayati di Wilayah Pesisir dan Laut Tropis. Yogyakarta: Pustaka Pelajar.

Susanto, H. Adi, Suraji, M. Takeshi. 2015. Management of Coral Reef Ecosystems in Indonesia : Past, Present, and The Future. Coastal Ecosystems 2: p. 21-41.

Tuwo, A. H. 2011. Pengelolaan Ekowisata Pesisir dan Laut: Pendekatan Ekologi, SosialEkonomi, Kelembagaan dan Sarana Wilayah. Brilian International. Surabaya.

Veron, J.E.N. \& M. Pichon. 1976. Scleractinian of Eastern Australia. I. Families Thamnasteriidae, Astrocoeniidea and 
Pocilloporidae. Australia Institute of Marine Science Monogr. Ser. 1, pp : 86-1.

Veron, J.E.N. \& M. Wijsman-Best. 1977. Scleractinian of Eastern Australia. II. Families Faviidae, Trachyphyllidae and Pocilloporidae. Australia Institute of Marine Science Monogr. Ser. $3: 233$ pp.

Veron, J.E.N. \& M. Pichon. 1979. Scleractinian of Eastern Australia. III. Families Agariciidae, Siderastreidae, Fungidae, Oculinidae, Merulinidae, Mussidae, Pectinidae, Caryophyllidae, Dendrophyllidae. Australia Institute of Marine Science Monogr. Series 4: $422 \mathrm{pp}$.

Veron, J.E.N. \& M. Pichon. 1982. Scleractinian of Eastern Australia. IV. Families Poritidae.
Australia Institute of Marine Science Monogr. Ser. $5: 159$ pp.

Veron, J.E.N. 1986. Coral of Australia and The Indo-Pacific. Institute of Marine Science, Townsvile, Australia.

Veron J.E.N. 2000. Coral ID (An electronic Scleractinian Corals of the World). Australia.Chou, L.M., 2000. Southeast Asia reef-status update : Cambodia, Indonesia, Malaysia, Philippines, Singapore, Thailand and Vietnam. In C. Wilkinson, Status of coral reefs of the world, CORDIO : p. 117-129.

Veron, J.E.N. 2002. Cheklist of Corals of Eastern Indonesia and the Raja Ampat Islands. RAP Bulletin of Biological Assessment 22: p. 90103. 